\title{
Pověsti o loupežníku Kováříkovi
}

\author{
Adam Votruba
}

DOI: $10.21104 / C L .2017 .4 .03$

\section{Legends about the Bandit Kovářík}

\author{
Abstract The article follows a narrative \\ tradition concerning the bandit Jan Vojta, \\ alias Kovárík (ca. 1744-1803). There is \\ evidence, collected in the first half of \\ the 20th century, which mentions the \\ existence of a vivid and extensive oral \\ tradition surrounding this noble robber. \\ Folklorists, however, did not pay attention \\ to this phenomenon. The author of this \\ article has managed to collect surviving \\ fragments of this tradition in the field in \\ Central-Eastern Bohemia. An interesting \\ fact is that Kovárík is one of the few bandits \\ in Bohemia who fit the definition of social \\ banditry proposed by English historian \\ Eric Hobsbawm. The tradition surrounding \\ him even shows some features which are \\ atypical for Bohemian bandits, and which \\ show him to be more similar to Slovakian
}

and East-Moravian (social) bandits. These include motifs such as the theft of cattle, cooperation with a reeve and participation in a peasant uprising. These findings could serve as inspiration for further historiographic research into this figure.

Keywords legends, bandits, social banditry, Jan Vojta Kovárík.

Contact Mgr. Adam Votruba, Ph.D., Škola Kavčí hory, K sídlišti 840, 14000 Praha 4, Czech Republic; e-mail: adam.votruba@seznam.cz.

Jak citovat / How to cite Votruba, Adam. (2017). Pověsti o loupežníku Kováříkovi. Český lid 104, 453-472. doi:http:// dx.doi.org/10.21104/CL.2017.4.03 
Střední Čechy jsou na loupežnické pověsti chudé, přesto však daly vzniknout jedné výraznější loupežnické postavě. Idealizující cyklus pověstí se soustř̌edil kolem Jana Vojty řečeného Kováŕíka, který působil koncem 18. století na pomezí tehdejšího kouřimského a čáslavského kraje. Jeho přízvisko, kterým bývá označován častěji než př́jmením Vojta, se objevuje ve tvarech Kovárík i Kovařík. ${ }^{1}$

Jan Vojta Kovářík určitě nepatří v rámci české folklorní tradice k nejvýznamnějším postavám (alespoň z hlediska dochovaného materiálu). Obdobných postav a postaviček najdeme přinejmenším desítky. V jeho případě však existují důvodné indicie pro domněnku, že ústní tradice kolem jeho osoby byla původně dosti rozsáhlá, ale pro nezájem folklorních sběratelů (nenašel se nikdo, kdo by se na toto téma zaměřil) se z ní zachovalo jen torzo.

Z životopisu Jana Vojty máme k dispozici pouze několik základních údajů. Téměř všechny práce, které se jeho osudem zabývají, čerpají z jediného zdroje - z kroniky jeho současníka Františka Vaváka. ${ }^{2}$ Výjimkou je téměř neznámá publikace Jana Valeriana Olivy z roku 1939 Po stopách předků. Tato rodová kronika obsahuje kapitolu věnovanou slavnému loupežníkovi, který pocházel z autorova rodného kraje. Najdeme tu řadu zajímavých údajů, bohužel bez přímých odkazů na prameny a zřejmě i s jistými nepřesnostmi. ${ }^{3}$

Kvůli omezenému rozsahu článku představíme Vojtův životopis jen ve zkratce. Narodil se někdy kolem roku 1744 v Žandově, zemřel 20. dubna 1803 na Špilberku. ${ }^{4}$ Loupežníkem se stal poté, co mu byla roku 1774 pro neplnění robotních povinností odebrána rolnická usedlost, kde hospodařil jako chalupník (Skopec, ed. 1915, 1918 - Vavákovy paměti, zde 1918: 34). Dopaden byl i se společníky roku 1794 (Skopec 1915: 125-126). Někdy v roce 1797 utekl ze Špilberku, znovu byl dopaden v lednu 1799 u rychtáře v Bohouňovicích (Skopec 1918: 33).

\section{Literární odraz kováříkovské „legendy“}

Ještě v první polovině 20. století se některé knihy odvolávají na Kováříkovu proslulost. Autor prvního historicky věrného životopisu Václava Babinského z roku 1922, novinář Karel Novotný, staví Kováříka do protikladu k Babinskému jako pravého „selského zbojníka“, přičemž mj. píše: i my, s výjimkou přímých citací, kde se řídíme originálem (v textu označeno odlišným typem písma).

2 Např. Francek, Procházka aj.

3 Téměř jistě je chybný rok narození 1733 (Oliva 1939: 86).

4 V Žandově nacházíme 5 novorozenců téhož jména v letech 1743, 1744, 1751, podle úmrtní matriky vychází rok narození na léta 1741/42, uvedený údaj o stáří však nemusí být přesný: Dostupné z: http://actapublica.eu/matriky/brno/ prohlizec/7900/?strana=132 [2015-12-23] (Moravský zemský archiv Brno). 
„Kovář́k byl geniální chlapík a dobrodružné historie o něm, které zaznamenal Vavák, šírily se po celé zemi, stávaly se legendami a mnohé $z$ nich, zvláště onen milostný moment při vyzrazení, prenesen byl také na Babinského. S plnou určitostí můžeme tvrdit, že Babinský se stal populárním z popularity Kováŕíkovy a dobrodružné historie lupičské přeneseny s Kovář́ḱk na Babinského.“(Novotný 1922: 17)

Popularitu Kováříkovu potvrzuje i Jaroslav Procházka, rodák z Kouřimska, ve své rodinné kronice vydané roku 1940:

„Lidové vyprávění hledělo vytvořit z Kováříka zbojníka podle vzoru slovenského Jánošíka a ještě minulá generace o něm vyprávěla př́hody hodně romantické.“(Procházka 1940: 136)

Máme tak k dispozici svědectví o značné proslulosti tohoto loupežníka, z nichž je zjevné, že tato popularita je rozvíjena ústním podáním. Víme, že v tomto podání se stává z Kováříka dobrý loupežník (který bohatým bere a chudým dává), dozvídáme se od Novotného, že folklorní motivy příznačné pro Kováříka přecházely později na Babinského.

Chybí nám však bližší představa o podobě této tradice. O zápisech pověstí bude řeč níže, ale můžeme předeslat, že až do roku 1995 byla o něm vydána jediná pověst, což se zdá být $\mathrm{s}$ uvedenými svědectvími v jistém rozporu, zvláště víme-li, že o jiných slavných loupežnících, jako Babinském či Janu Jiřím Graselovi, byly zaznamenány desítky vyprávění.

V literatuře nenacházíme ani žádný folklorní motiv. Nelze za něj považovat zmínku o přestrojení za myslivce, která se objevuje u Vaváka a které si následně všímá Dagmar Klímová (Klímová 1983: 189). Tato informace se u Vaváka objevuje na dvou místech, přičemž zejména druhá formulace svědčí o tom, že jde o hodnověrně zjištěnou skutečnost:

„Nalezeno u něho též 1 dobrá flinta, jedny o jednom rohu podávky, 2 britvy a dva talíre hliněné, též cop a pletenec na kadeře, neb on někdy jako myslivec v copě, někdy jako měštan v krátkých zakroucených vlasech a někdy jako sedlák chodil.“(Skopec 1918: 33)

Za jediný jednoznačně folklorní prvek ve Vavákově zápisu lze považovat místo, kde cituje v souvislosti s rozmachem loupežnictví jedno lidové přísloví. Na pomezí kraje kouřimského a čáslavského v okolí Žandova a Jindic prý „po všechny časy př́sloví trvá, že v Žandově a v Jindicích jest poctivý člověk k nalezení jak bílá vrána“ (Skopec 1915: 123).

Za doklad narativního motivu bychom mohli považovat výše uvedený citát z Karla Novotného, kde se hovoří o „milostném momentu při vyzrazení, který měl být přenesen z Kováŕíka na Babinského. Není ovšem zřejmé, co měl 
Novotný na mysli. Kovářík byl chycen dvakrát, poprvé se tak stalo v domě jeho sestry přičiněním švagrovým, podruhé se skrýval u rychtáře a vyzrazen byl „skrze jednu děvečku“ (Skopec 1918: 33). Nic více o okolnostech vyzrazení Vavák nepraví. Novotný mohl mít na mysli nějaký motiv z jemu známé ústní tradice, o němž však blíže nepojednal.

Výjimečným písemným pramenem pro poznání kováříkovské tradice je hra pro loutkové divadlo z první poloviny 19. století. Hra byla připisována Prokopu Konopáskovi (1785-1828), učiteli v Olešné u Rakovníka (Bartoš 1959: 187-206).

Není situována do regionu, kde Kováŕík působil, nýbrž na Rakovnicko. Loupežníci mají svůj brloh na zrrícenině Džbán a ve hře se vyskytuje i místopis dalších okolních obcí. Zdá se, že autor zdejší krajinu znal. ${ }^{5}$ Loupežníci zde vystupují spíše jako negativní živel - na závěr hry jsou pochytáni a spravedlivě potrestáni. Kovář́k jedná jako lstivý loupežnický hejtman, který je přesvědčen o své chytrosti, najde se však člověk, který dokáže přelstít i jeho. V textu se na dvou místech objevuje motiv, podle něhož loupežník bere bohatým a dává chudým, ale autor hry se patrně s tímto míněním neztotožňuje. Spíše se zdá, jako by svými formulacemi s lidovou legendou polemizoval:

DÍVKA: On má být ten Kovářík velmi hodný pán;

on jen bohatým bere a chudým rozdává.

KOVAŘÍK: Dobře dělá. Bodejt', aby chudým bral a snad

těm bohatým dával? (Bartoš 1959: 190)

Ještě zajímavější je skutečnost, že divadelní hra obsahuje zjevně motivy pocházející z pověstí. Je to jednak vyprávění o tom, jak loupežník podaruje sedláka v nouzi a nařídí mu, aby pro něj uchystal hostinu. Když se posléze ve vsi rozkř̌ikne, že k sedlákovi má přijít Kovářík, obklíčí vojáci sedlákovo stavení, jenže loupežníci nepřijdou a místo toho mezitím vyloupí slabě střežený zámek. Dalším folklorním motivem je potrestání ženy, která loupežníka pomlouvá, nevědouc, že mluví právě s ním. Kováŕík ji nechá posadit na prkno pobité hřeby a jazyk jí nechá dát do skřipce.

Obě historky patří k ustáleným vypravěčským látkám, které jsou připojovány k různým loupežnickým postavám. S oběma látkami zároveň se můžeme setkat u Babinského a Grasela (Hruschka [1933]: 79-81, 82-84; Jermář 1995: 20-21, 21-22), jednotlivě je nacházíme u řady dalších loupežníků, nejen českých. Druhá historka je patrně nejrozšířenější loupežnickou pověstí v českých zemích a na Slovensku vůbec. ${ }^{6}$ Obvyklým způsobem potrestání pomlouvačné ženy je posazení na cvočky, které loupežník předtím vysází na pařez.

5 Topografickou nepřesností jsou zmínky o hradu Přimdě. Zřejmě mělo jít o zříceninu hradu Pravda v blízkosti Džbánu, omyl mohl vzniknout při opisování hry.

6 Pověst najdeme i ve Slovinsku či v někdejším pruském Slezsku, naopak v Německu se nevyskytuje (Votruba 2010: 124; Petzoldt 1993: 217-218; Peuckert 1966: 41). 
V dalších variantách se objevuje nabití hřebíků do zadku nebo do pat (časté na Slovensku), vzácněji posazení do mraveniště (Salichová 1951: 168-169; Gašparíková 1964: 94, 197). Prkno pobité hřeby a jazyk zavřený do skřipce jsou v tomto kontextu neobvyklé, ale souvislost syžetu je zřejmá.

Z uvedených skutečností lze usuzovat, že autor při psaní hry využil pověsti, které se o loupežníkovi Kováříkovi v první polovině 19. století tradovaly. Naproti tomu ze skutečného Kováŕíkova života neví nic. S pověstmi se mohl nejspíše setkat na Rakovnicku, kam je hra zasazena. Příznačná je právě skutečnost, že jde o obecně rozšířené loupežnické látky. Kdyby žil autor v Kováŕíkově regionu, tedy na Kouřimsku či v Posázaví, nutně by v této době narazil ještě i v ústním podání na zprávy, které se vztahují k reálnému životu Jana Vojty. Naopak v odlehlejším regionu, kam se donesla sláva Kováŕíkova jména odjinud, se s ním spojila jen obecnější anekdotická vyprávění.

Na základě těchto zjištění se zdá velmi pravděpodobné, že se na Rakovnicku pověsti o Kováŕíkovi dříve tradovaly, ale jejich zápisy se nedochovaly. I mé vyptávání mezi pamětníky bylo v tomto směru bezvýsledné.7

Historku s posazením na cvočky máme ovšem doloženu ve spojení s Kováříkem v pozdějším zápise z Plzeňska, o němž se ještě zmíníme. Druhý motiv, který bychom mohli označit jako Loupež během ohlášené hostiny (Votruba 2010: 124), se mezi zapsanými pověstmi ke Kováříkovi nenachází.

Hry lidových loutkářů nelze považovat za lidové v témže smyslu jako lidové pověsti či písně. Nejde o folklorní útvar zformovaný v procesu ústního podání jako v zásadě kolektivní dílo. Lidové hry se svou povahou blíží spíše kramářským písním než ústní slovesnosti. To bychom měli mít na paměti i při posuzování hry o Kováříkovi, nebot se zdá, že pro ni platí totéž, co pro kramářské písně a loupežnické romány. $\mathrm{V}$ těchto literárních dílech není nikdy idealizace loupežníků bezvýhradná, do zpracování pronikají výchovné a moralizující tendence. Byt' lze vyjádřit v menší míře sympatie k loupežnickému hrdinovi, nikdy nelze pochybovat o oprávněnosti trestu. V ústním podání se naproti tomu s moralizujícími tendencemi téměř nesetkáme (Votruba 2010: 213). O kováŕíkovské hře platí to, že ačkoliv bezpochyby čerpá z lidových pověstí, její celkové vyznění odpovídá charakterem spíše románu či kramářské písni, kde loupežnický vůdce i přes jisté sympatické rysy je koneckonců zločincem, který má být po zásluze potrestán.

\section{Pověsti o Kováříkovi}

V publikacích vydaných před rokem 1995 nacházíme jedinou pověst věnovanou loupežníku Kováŕíkovi. Zapsal ji Jaroslav Schiebl od paní Střížkové z Plzně a otiskl ji roku 1933 ve sbírce plzeňských pověstí (Schiebl 1933: 3637). O Kováŕíkovi se zde vypráví, že posadil na cvočky starou výměnkářku, 
která o něm špatně mluvila. Jde tedy o putovní motiv posazení na cvočky, s nímž jsme se setkali v loutkové hře. Dále se zde dozvídáme, že Kováříka pomohl chytit jakýsi student David, který se k němu dal najmout za kuchtíka, a že Kováríka nakonec pověsili. Toto tvrzení pochopitelně neodpovídá historické skutečnosti.

Je na první pohled možná paradoxní, že tato pověst byla zapsána na Plzeňsku a nikoliv v kraji Kováŕíkova působení. (Samotný děj pověsti je mimo to situován do plzeňských lesů.) O tom, že nedostatek zapsaných pověstí je v pozoruhodném rozporu se svědectvími o živoucí kováříkovské legendě (tato svědectví jsou z první poloviny 20. století), jsme se již zmínili.

V nejstarších sbírkách pověstí z Kouřimska a Čáslavska se o Kováříkovi nic nedovídáme. Tůmovy Staré pověsti zlické z roku 1916 nebo Schneiderovy Staré pověsti a báje zlické z Kolínska, Kouřimska a okolních okresů z roku 1934 o něm mlčí, stejně tak v Čáslavi vydaná Kytička pověstí od J. Mrštíka a J. Prchala. Teprve v době poměrně nedávné se začíná Kováŕík objevovat v publikacích tohoto druhu. Několik textů nacházíme v knize Od Sázavy k Labi od Bohumila Pospíšila z roku 1995, popřípadě u Martina Drahovzala v publikaci Pověsti a kratochvilná vyprávění z Kouřimska a Kolínska (2007).

Nabízí se otázka, odkud se náhle berou v Pospíšilově publikaci čtyři poměrně rozsáhlá vyprávění o Kováŕíkovi. Odpověd' nám poskytne útlý strojopis pod názvem Loupežnické povídky historické, který sepsal ve Zbýšově Alois Ryšán a který je datován rokem $1954 .{ }^{8}$ Spis, který autor věnoval své manželce „Boženě, rozené Čenské, horlivé čtenářce románů a povídek“, si zaslouží naši pozornost. Je však zřejmé, že texty v něm obsažené ve skutečnosti pověstmi nejsou. Jde toliko o povídky inspirované mj. i pověstmi. Čtenáři knížek, kterým se tyto příběhy prezentují bez dalšího vysvětlení jako pověsti, jsou tedy jistým způsobem klamáni.

Zde je snad na místě pokusit se o vysvětlení této situace. Samotný pojem „pověst“ obsahuje v sobě zárodek nedorozumění, který je odborníkům dobře znám. Folklorista považuje za pověst vyprávění, jež je v původním prostředí vnímáno jako pravdivé (nebo se tak alespoň tváŕí), ${ }^{9}$ laická veřejnost si však s tímto pojmem spojuje spíše knižní produkci vybájených příběhů z minulosti. Žánr pověstí tak začal skrze literaturu plnit specifickou společenskou úlohu, kterou původně neměl a kterou bychom snad mohli popsat jako magické vztahování se $\mathrm{k}$ minulosti a krajině. Laická produkce knih pověstí odpovídá na tuto potřebu a vzdaluje se původnímu významu slova, nebot́ tex-

8 Rukopis je uchován v SOkA v Kutné Hoře.

9 Někteři etnologové naproti tomu zdůrazňuji jako typický znak pověsti „očekávání rozporu“. U nás např. Jan Luffer s odvoláním na folkloristku Lindu Déghovou (Luffer 2014: 13). Nechci popírat platnost tohoto postřehu, domnívám se však, že jde o záležitost příznačnou spíše pro numinózní pověsti, nikoliv historické. Možno zde uvést autopsii německého folkloristy Oskara Schwära, když vzpomíná na vypravěčské večery, které zažil v dětství na hornolužické vesnici. Při strašidelných historkách měli posluchači ohledně pravdivosti nejednoznačné pocity, ovšem vyprávění o loupežníku Karáskovi byla prý vnímána jako nepochybně pravdivá (Schwär 1961: 84-85). 
ty publikovaných „pověsti““ jsou dosti svévolně upravovány a konstruovány za použití různých zdrojů i ryze estetických měřítek. Svědčí o tom i rozhovory s autory, kteří se sice odvolávají na ústní podání jako jeden ze zdrojů, ale na přímé dotazy, co vlastně pro určitý text načerpali z ústního podání, nejsou často schopni odpovědět. ${ }^{10}$ Důsledkem této tendence je skutečnost, že současné edice „objevuji““ nové pověsti, které ve starších sbírkách nenajdeme a které při bližším ohledání žádnými pověstmi nejsou.

Na přístupu Aloise Ryšána je cenné, že odděluje své literární zpracování od folklorních podnětů i od historické reality. Čtenáře informuje o tom, co ho při psaní inspirovalo. Ačkoliv si tedy nepočíná jako folklorista, jeho dílo má pro folkloristy svou výpovědní hodnotu. V předmluvě Ryšán píše:

„Když jsem se počal zajímati o minulost Zbýšova a okolí, byla tu řada lidí, kteři se narodili kol. roku 1850. Ti ještě z podání svých rodičů a prarodičů ledasco o Kovař́kovi věděli. Jejich zprávy kusé byly mi podkladem při psaní povídek Kovaříkova podkova a Kostelník Horák [...] Námětem povídky Strýček Vojtěch bylo mi stručné sdělení děkana P. Václava Žižky, faráře ve Zbýšově, u jeho činnosti matrikáře. “(Ryšán 1954: 1)

Ryšánovo dílo obsahuje celkem čtyři texty: reálný životopis Kováříka a tři povídky. V životopisném textu je věnována zvláštní pozornost osudům farního statku v Damírově, který měl Kovářík čtyřikrát vyloupit; nakonec prý zbyla faráři jen košile a klerika.

Obsah povídek je ve stručnosti tento:

1. (Kováŕíkova podkova) Zbýšovský mlynář zachránil Kováŕíka před pronásledováním, ten mu za to daroval prasnici a podkovu, která poté tomu, kdo ji měl, přinášela štěstí.

2. (Kostelník Horák) Bratři Kováŕíci se pomstili tupadelskému správci za to, že je chtěl lapit. Nutili ho v hospodě pít a platit a pak předstírali jeho pohřeb, který skončil hozením správce do jámy na vápno.

3. (Strýček Vojtěch) Podruh z Dobrovítova u sebe nechá nemocného Kováříka až do uzdravení, ten mu věnuje tolar, který se v rodu dědí po ženské linii z matky na dceru.

Důležitá jsou pro nás ta místa, kde autor hovoří o kováříkovské tradici přímo. Takto například v úvodním životopisu charakterizuje ústně tradovaný obraz loupežníka:

„Chodíval $v$ prestrojení za lesníka s copánkem pod mysliveckým kloboukem, za krajánka, jindy jako sedlák v krátké haleně a širokém klobouku. Několikráte i s celou tlupou navštívil zbýšovskou hospodu,

10 Vedl jsem na toto téma rozhory s regionálními autory M. Drahovzalem, V. Zieglerem a B. Baláčkem. První z nich uvedl, že z ústního podání použil o Kováŕíkovi zhruba jednu větu, ale nepamatuje si, oč šlo. 
kde vesele řádíval, hostil a platil za všechny prítomné. Mnoho a dlouho se o něm vypravovalo. Jistě, že časem vše, co se opravdu stalo, bylo zveličeno a zkresleno, takže po mnoha létech v řeči lidu se Kovař́k jevil někdy jako strašný zločinec, jindy jako mstitel za útrapy poddaných a i jako člověk, který mnohým dobro udělal.“ (Ryšán 1954: 3)

Zajímavé je Ryšánovo vyprávění o tom, jak se poprvé setkal s poznámkou o Kováríkově podkově, což prý ho vedlo k dalšímu pátrání a objevení pověsti, kterou poté zpracoval do jedné z povídek:

„Brzy po první světové válce se v hloučku hospodářru hovořilo o sedlákovi, jehož dobytek nejen pro krásu, ale i pro užitek byl obdivován. Rozhovor zakončen byl slovy jednoho, který se řeči dosud nezúčastnil: ,To jinak není, ten má doma jistě Kovaříkovu podkovu‘. “(Ryšán 1954: 8)

Je zřejmé, že použije-li mluvčí takovouto průpovídku, počítá s tím, že přítomným je příběh o Kováříkově podkově natolik znám, že není třeba narážku blíže vysvětlovat. To opět prozrazuje, jak mnoho byla tradice k postavě Jana Vojty v té době ještě silná. Narážku obdobného druhu nacházíme i ve větě, kterou Ryšán (učitel ve Zbýšově) údajně slyšel v roce 1912: „Však nebýt Kovaříka, špacíroval byste pěkně po Damírově. “(Ryšán 1954: 4) V Damírově panovalo obecné přesvědčení o tom, že Kovářík připravil obec o faru a o školu. Několikeré přepadení damírovské fary mělo vést k tomu, že roku 1800 byla fara raději přestěhována do Krchleb; v témže roce došlo i k přestěhování školy do Zbýšova. Alois Ryšán ovšem upozorňuje, že přesun fary do Krchleb byl plánován již dříve a Kováříkův přepad damírovské fary záležitosti pouze urychlil. Ryšán nás tedy zpravuje o mylném historickém povědomí damírovských, které se zde tradovalo ještě „100 let po loupeži“ (Ryšán 1954: 4) a které lze zároveň chápat jako již zformovanou etiologickou pověst.

Ryšánův spisek nám tedy potvrzuje starší stručná svědectví o tom, jak živá byla tradice o Kováŕíkovi v regionu, kde působil, ještě v první polovině 20. století. Nic to však nemění na tom, že se odtud nedochovaly žádné zápisy pověstí, takže jediná známá pověst o Kováŕíkovi pochází poněkud paradoxně z Plzně.

V této situaci jsem se pokusil provést na Kouřimsku a Čáslavsku terénní výzkum s cílem zapsat pokud možno ještě některé vyprávění o loupežníku Kováříkovi. Zdálo by se, že na počátku 21. století, při dnešních kulturních podmínkách a více než 200 let od smrti této historické osobnosti, nemá takové počínání šanci na úspěch. Je to jistě do značné míry pravda, ukázalo se však, že podobný předpoklad nemusí platit stoprocentně. ${ }^{11}$

11 Proběhlo přímé osobní dotazování pamětníků v obcích Žabonosy, Jindice, Žandov, Pivnisko, Horní Kruty a v dalších lokalitách. Následně jsem se pokusil oslovit telefonicky či písemně kronikáře z asi 50 obcí v regionu, tento způsob však přinesl již jen zanedbatelné výsledky. Následný týmový folkloristický výzkum v okolí Kouřimi 2016 doložil jen přežívající povědomí o Kováŕíkově osobě. 
Celkem se podařilo zachytit tři většinou stručná vyprávění, která lze klasifikovat jako pověsti a u nichž lze předpokládat, že zachycují kontinuálně dochovanou ústní tradici. Pamětníci, kteří dokázali o Kováŕíkovi něco říci, se většinou narodili ještě ve 20 . letech 20 . století. Jedna další zmínka, kterou jsem zapsal z ústního podání, měla prokazatelně svůj původ pouze v literárním zpracování, respektive šlo o historické povědomí o Kováŕíkovi, které bylo revitalizováno četbou v jen velmi nedávné době, proto je nepřiřazuji k citovaným pověstem..$^{12}$ Stranou musím nechat i nejasnou zmínku o momentu proticírkevním. ${ }^{13}$

Stručný obsah zapsaných pověstí je tento:

1. Kovářík byl ve spojení s rychtářem Vedralem v Bohouňovicích a schovával si u něj lup, Bohouňovičtí pak svého rychtáře vyhnali. (Horní Kruty) (Votruba 2013: 73)

2. Kováŕíkova banda loupila tak, že někteří seděli s bohatými statkáři v hospodě a hráli karty, druzí mezitím loupili. Občas nechali někomu chudému za dveřmi kus masa z lupu. (Žabonosy)

3. Kováŕík se podílel na povstání proti baronovi a táhl s povstalci na zámek do Červených Peček. (Žandov, Pivnisko)

Všechna tři vyprávění obsahují motivy, které ve starších zápisech o Kováŕíkovi nenacházíme. Literárně ovlivněno se zdá být vyprávění první, které ke Kováříkovi přináší jen povšechné informace (někdy nepřesné), jež jsou navíc obecně dostupné. Domnívám se, že tyto informace pocházejí přinejmenším z části z již zmíněné knihy Jaroslava Procházky, která je v Horních Krutech a okolí poměrně známá, a to i mezi blízkými známými vypravěčky. Na vyprávění je bezpochyby zajímavější svědectví o rodině rychtáře Vedrala, který Kováříka ukrýval, i s patrně nesprávnou informací, že bohouňovičtí svého rychtáře kvůli spojení s loupežníky vyhnali. ${ }^{14}$

Třetí vyprávění obsahuje kontaminaci dvou nesouvisejících historických entit. Osoba loupežníka Jana Vojty je dávána do souvislosti se selským povstáním z roku 1713. K tomuto propojení zjevně přispělo to, že jedním z aktérů povstání byl Kováříkův jmenovec, žandovský rychtář Ondřej Vojta (Volf 1934: 108). Zdálo by se, že může jít toliko o omyl vypravěče, tuto informaci však uvedli nezávisle na sobě tři osoby v Žandově a Pivnisku, přičemž jejich výpovědi se týkaly „Kováŕíka“, nikoliv „Vojty“. ${ }^{15} \mathrm{~V}$ Pivnisku doplnil vypravěč ještě tvrzení, že Kováŕík pobýval v obci v čísle popisném 23, a také, že byl

12 Podle tohoto svědectví byly celé jindice ve spojení s Kováříkovou bandou; Kovářík odtud pocházel a v okolních vesnicích se všichni Jindičanů báli. Vypravěčka zároveň uvedla, že se to nedávno dozvěděla od známé, která to vyčetla z knížky. Sdělila paní Vlasáková, Rašovice, únor 2015.

13 Dva historicky poučení lidé uvedli, že přepadení damírovského faráře mohlo souviset s tím, že farář pronásledoval nekatolíky. Prezentovali to spíše jako svou hypotézu. Starší žena ze Senetína uvedla, že se říkalo, že dotyčného faráře přepadli evangelíci. 
ve spojení s mlynářem v lištínském mlýně. Tato informace ovšem opět upomíná na povstání, k jehož vůdcům mlynáŕ Jiřri Pokorný patřil (Volf 1934: 108).

Klasické představě loupežnické pověsti se nejvíce blíží podání z Žabonos. Motiv, podle nějž část loupežnické bandy hrála s bohatými statkáři karty v hospodě, zatímco ostatní loupili na statku, uplatňuje oblíbené schéma loupežnické lsti. Podobný model nacházíme v již zmíněném motivu loupež během ohlášené hostiny a mnoha dalších látkách, například v narativním i baladickém motivu okradená krčmářka, kdy vůdce loupežníků tančí se šenkýřkou, zatímco jeho kumpáni loupí v budově hostince (srov.: Jermář 1995: 26; Gašparíková 1979: 113-114). Tyto a podobné motivy se vyskytují i v pohádkách a humorkách (např. ATU 1525-1527*). Žabonoská pověst líčí toto lstivé počínání jako obecnou strategii bandy, nikoliv jako jedinečnou událost, nelze však vyloučit, že původně mohlo jít i o příběh jedné konkrétní loupeže a že do obecné polohy se motiv dostal ve fázi doznívání tradice. ${ }^{16}$ Nepodařilo se zjistit, že by se tento motiv uplatňoval v pověstech o jiných loupežnících.

Svědectví vypravěčky ze Žabonos obsahuje i několik dalších zajímavých detailů. Vyprávění o Kováříkovi slýchala dle vlastních slov v dětství při draní peří od starších žen. To, co byla schopna reprodukovat, byl zřejmě jen malý výsek toho, co v dětství na toto téma slýchala. Za pozornost stojí zmínka o tom, že Kováŕíkova banda loupila dobytek, což odpovídá i historické skutečnosti, přičemž pro loupežnické pověsti z Čech není tento motiv obvyklý. Navazuje na něj zmínka o podarování chudých lidí kusem masa, k čemuž vypravěčka uvádí i konkrétní rodinu v obci, která měla být takto obdarována.

Naproti tomu v literatuře se objevující tvrzení, že Kovářík ukradl v Žabonosech kostelní zvon (údaj lze najít v obci i na nedávno nainstalované turistické tabuli), vypravěčka odmítá. Uvádí, že v kostele kdysi někdo chtěl krást, ale jistý občan, který bydlí poblíž, zloděje vyrušil. Tímto zlodějem však podle ní určitě nebyl Kováŕík. ${ }^{17}$ Tento moment podtrhuje autenticitu zachycené tradice a její nezávislost na psaném slovu.

Zmíněné uloupení kostelního zvonu Kováříkem mohlo snad též figurovat $\mathrm{v}$ místě jako pověst, bezprostředně se však tento motiv nepodařilo $\mathrm{z}$ ústního podání doložit. $\mathrm{V}$ řadě publikací je tato loupež popsána jako skutečná událost, zároveň s informací, že ve věži žabonoského kostela měl Kovářík zbudovaný úkryt. Hovoří o tom například Alois Ryšán (1954: 3) nebo Jan Oliva (1939: 91).

Lze shrnout, že celkově máme k dispozici čtyři zapsané pověsti k postavě Jana Vojty Kováŕíka a několik narativních motivů doložených prostřednictvím jiných pramenů (Ryšánův rukopis, hra Jan Kovařík). To nám spolu s drobnějšími zmínkami o oblibě kováříkovské tradice umožňuje tuto tradici nadneseně 
řečeno rekonstruovat, respektive utvořit si poměrně věrohodnou představu o jejím významu v kontextu středoevropských loupežnických látek.

\section{„Rekonstrukce“ kováříkovské tradice}

Provádí-li se dnes terénní výzkum zaměřený na loupežnické pověsti, je takové počínání možno přirovnat k archeologii. Sběratel potřebuje určitou dávku štěstí, aby mu bylo dopřáno zachytit alespoň střípky někdejší tradice. Již v 80. letech 20. století se v souvislosti s loupežnickými pověstmi hovořilo o zánikovém stadiu tradice (Šalanda 1988: 113).

Domnívám se, že existuje řada důvodných indicií pro hypotézu, že kováříkovská tradice byla původně poměrně rozsáhlá. Přesvědčují nás o tom různá svědectví a skutečnost, že regionální povědomí opakovaně motivovalo místní autory, aby se kováŕíkovskému tématu věnovali. Také moment, že pověsti o Kováŕíkovi byly vyprávěny daleko od jeho působiště (zápis z Plzeňska a nepřímý doklad z Rakovnicka), bývá charakteristický pro známější loupežnické postavy. Z toho důvodu považuji za odůvodněnou hypotézu, že množství pověstí tradovaných o Kováŕíkovi mohlo být obdobné jako v př́ípadě folklorně nejslavnějších českých loupežníků jako Babinský, Grasel a Karásek. K těmto postavám se pojí nejméně 26-34 zapsaných vyprávění (Votruba 2010: 396, 402, 407).

Důvodem pro skromný počet existujících zápisů ke Kováŕíkovi by tak byl jednoznačně nezájem sběratelů o toto téma. Stojí za zmínku, že například za drtivou většinu zapsaných pověstí o Karáskovi vděčíme jedinému sběrateli - Oskaru Schwärovi, který je zapsal v 50. letech. Dříve tyto pověsti v regionu žily, sám Schwär je v dětství slýchal, ale sběratelé se o ně (až na ojedinělé výjimky, které představují příznačně numinózní pověsti o pokladech) nezajímali (Votruba 2010: 396). Podobně za rozhodující část zapsaných pověstí o Graselovi vděčíme Rudolfu Hruschkovi. Lze tedy konstatovat, že z folklorního podání se pro budoucnost uchovává jen to, co nepropadlo sítem sběratelského zájmu.

Pokoušíme-li se vysvětlit původ pověstí k některé historické osobě loupežníka, nacházíme několik základních způsobů jejich utváření:

1. Vliv existujících putovních motivů, které jsou přenášeny ústním tradováním z jedné historické postavy na postavu jinou.

2. Vypravěčské motivy, jež mají svůj původ v reálném životě zločince (často se relativně věrně uchovávají informace o smrti dané osoby).

3. Vliv literárního románového zpracování, pokud takové existuje. (V případě Kováŕíka chybí.)

4. Specifickým př́ípadem jsou vyprávění, která propojují loupežníka s reálnými událostmi, v nichž on sám aktérem nebyl. Tento případ se v podstatě blíží fungování putovních motivů s tím rozdílem, že jsme schopni popisovaný děj spojit s reálnou událostí, zatímco v případě putovních motivů jde 
o obecné látky oblíbené pro svůj zajímavý syžet, které však nejsou historicky doložitelné.

Zdá se, že nejvýrazněji se při formování tradice projevují právě putovní motivy, na druhém místě k nim přistupuje historická realita, literární vlivy bývají až na třetím místě (Votruba 2010: 130, 210). Vždy však zůstává část pověstí, jejichž původ není možné žádným z uvedených způsobů uspokojivě vysvětlit.

Obecně lze říci, že při utváření obrazu loupežníka v ústním podání se spojuje formativní vliv starší tradice o určitém typu postav s obecně známými skutečnostmi ze života této osoby. I na Kováŕíka nepochybně přecházely putovní motivy z pověstí o jiných historicky starších loupežnících, jejichž jména se nám možná ani nedochovala. Z Kováříka zase tyto motivy přecházely na Babinského, jak potvrzuje např́́klad Karel Novotný.

U realistických motivů z Kováŕíkova života není úplně jasné, nakolik se na jejich zachování podílela vzpomínková literatura (Vavák, Procházka). Patří k nim zejména spojení s rychtářem Vedralem, útěk ze Špilberku a snad i povědomí o jeho rodišti v Žandově, které je někdy mylně (zřejmě i pod vlivem Vavákovým) kladeno do Jindic.

Pozoruhodné je zmiňované propojení Kováříka s nesouvisejícími historickými událostmi, zejména se selským povstáním roku 1713. Za pozornost stojí ale i plzeňské vyprávění o jeho chycení a popravě. Mělo se tak stát za přispění jakéhosi studenta Davida, který se nechal loupežníky najmout za kuchtíka a pak bandu zradil. Nápadná je zde podobnost se skutečnými osudy Jana Jiřího Grasela, který byl chycen díky konfidentu Davidu Mayerovi, jenž se nejprve vetřel do Graselovy přízně (Francek 2002: 242). Na možnost přenosu této historické látky ukazuje jméno studenta-kuchtíka, i skutečnost, že podle plzeňské pověsti byl Kováŕík oběšen, zatímco ve skutečnosti takto skončil svůj život Grasel. Ostatní údaje však nesouhlasí: místo chycení a tvrzení, že se David měl stát plzeňským purkmistrem. Přesto lze s jistou mírou pravděpodobnosti usuzovat, že mezi plzeňskou pověstí a Graselovými osudy existuje spojitost.

Vzhledem ke zlomkovitému charakteru dochované tradice o Kováŕíkovi se nabízí otázka, co v dochovaných zápisech chybí. Nápadná je ve srovnání s podáními o jiných loupežnících zejména absence podání o pokladech. V regionu jeho působení také postrádáme nejběžnější putovní motivy (např. posazení na cvočky). Je spíše pravděpodobné, že dříve takové pověsti kolovaly.

\section{Postava Kováříka v kontextu dichotomie zbojník-loupežník}

Jan Vojta Kovářík patří jakožto folklorní postava do kategorie dobrých loupežníků, kteří dle tradice bohatým brali a chudým dávali. Tento atribut si v našem jazykovém povědomí běžně spojujeme s výrazem zbojník. Pečlivé zhodnocení kováŕíkovské tradice se tudíž nemůže vyhnout fenoménu zbojnictví. 
Zbojnictví, jak bylo popsáno historiky, je v podstatě univerzálním jevem, který se vyskytuje ve všech typech feudální společnosti (Hobsbawm 1969: 14). Anglický historik Eric J. Hobsbawm pro ně razí pojem „social banditry“. Zbojnictví chápe jako specifickou formu organizované loupežnické činnosti, kdy mezi zbojníkem a venkovanem není nepřátelství, zbojníci požívají ochrany venkovské komunity a jsou zde dokonce považováni za hrdiny (Hobsbawm 1969: 11). Důraz na postoj venkovské komunity ke zbojníkům kladou i další historici (Horváth 1988: 408).

V československé historiografii se vžil pro sociální banditismus pojem zbojnictví (resp. zbojníctvo), který navazuje na významový odstín mezi slovy loupežník a zbojník, jak jsou vnímána v běžném jazyce. Je však třeba zmínit, že tento rozdíl je až záležitostí spisovného jazyka. V mluvě českého a slovenského venkova neexistoval mezi těmito slovy rozdíl významový, nýbrž jen teritoriální. Slovo zbojník se užívalo na Slovensku a na východní Moravě, zatímco slovo loupežník bylo jeho synonymem v Čechách a na zbytku moravského území. Dokladem mohou být folklorní texty: v Čechách jsou dobří loupežníci vždy loupežníci, ${ }^{18}$ na východní Moravě nacházíme také zlé zbojníky.

Přesto má dnešní významový rozdíl určité historické kořeny. Oblast karpatského oblouku (východní Morava, Slovensko atd.) byla oblastí s hojným výskytem zbojnictví ve smyslu sociálního banditismu. Na západ od Karpat bylo zbojnictví, přinejmenším od 17. století, zcela okrajovým jevem. Naopak se zde běžně setkáváme s tzv. obyčejnými lupiči, kteří podle Hobsbawma (Hobsbawm 1969: 31) či podle německého historika Carstena Küthera (Küther 1987: 145) měli své sociální zázemí v lidech na okraji společnosti - v potulné vrstvě, př́íslušnících nepočestných povolání apod. K těmto obyčejným lupičům patří u nás právě Babinský či Grasel (Votruba 2010: 32-34).

Ve folklorní tradici se tyto historické podmínky odrazily tak, že sice i v Čechách a v Německu existuje podání o loupežnících, kteří bohatým brali a chudým dávali, ale význam této tradice je relativně skromný. Kult karpatských zbojníků představuje mnohem výraznější fenomén, vedle několikanásobně vyššího počtu narací se projevuje i výskytem písní, tanců, výtvarného lidového umění se zbojnickou tematikou a dalšími kvalitativními rozdíly (Votruba 2010: 252).

Jan Vojta Kováŕík představuje v tomto kontextu určitý specifický př́ípad. Už skutečnost, že pocházel z rolnického prostředí a nacházel v něm své zázemí, naznačuje, že bychom ho dle definičních kritérií měli považovat spíše za zbojníka. Jednoznačný soud by však měl zohlednit i sociální původ dalších členů bandy. Takové údaje zatím nejsou k dispozici. Není též jasné, jestli by Kováŕík měl v tomto ohledu představovat výjimku, nebo zda podobných loupežníků bylo více.

18 Ivan Olbracht dokonce používá v návaznosti na tradiční ideu ušlechtilého loupežníka dichotomii loupežník-lupič. (Olbracht 1982: 79). 
Z tohoto hlediska není bez zajímavosti, že Kovářík je jediný, nebo jeden z mála loupežníků v Čechách, pro něhož se začalo spontánně používat slovo zbojník. Používá ho například Karel Novotný (,selský zbojník“; Novotný 1922: 18) a použili ho i někteří informátoři, s nimiž jsem se setkal při terénním výzkumu („On to byl takovej zbojník. “). ${ }^{19}$ Ve starších pramenech se však tohoto výrazu k označení Kováříka nepoužívá, je ho tedy třeba chápat jako novodobější záležitost.

V kováŕíkovské tradici také nacházíme určité rysy, které jsou v kontextu českých loupežnických látek ojedinělé, ke kterým však nacházíme paralely v tradici karpatské:

1) časté loupeže dobytka,

2) spojení s váženými lidmi na vsi (např. s rychtářem),

3) účast na povstání.

První dva aspekty jsou v karpatské tradici poměrně běžné. Krádeže dobytka (zejména ovcí a krav) jsou nejenom opakujícím se námětem karpatských pověstí, ale patrně plnily i rituální funkce, jak naznačuje stylizované lidové podání z pera Jana Kobzáně; podle Kobzáně se věřilo, že krádeže přispívají ke kvalitě chovu (Kobzán 1984: 61). Podobně je tomu i v případě napojení zbojníků na vážené osoby z vesnické komunity. Pověsti připomínají, že do zbojnictví bývali zapojeni i vážení a bohatí sedláci, pamatují na to, že Ondráš byl synem fojta, apod. (více dokladů viz: Votruba 2010: 409-416).

Je třeba zdůraznit, že tyto motivy se do kováŕíkovského podání dostaly jako ozvuk historické reality. To vysvětluje, proč se zde nacházejí prvky, které v jiných loupežnických pověstech z Čech nejsou. Reálné je Kováŕíkovo spojení s rychtářem v Bohouňovicích, $\mathrm{k}$ čemuž nacházíme bezprostřední paralelu například u slovenského zbojníka Michala Vdovce (Gašparíková 1964: 93). Stejně tak je bezpečně doloženo, že krádeže dobytka hrály v činnosti Kováŕíkovy bandy důležitou roli (Skopec 1915: 126).

Bylo by jistě lákavé přičíst tyto karpatské paralely skutečnosti, že Kováŕík byl v Čechách ojedinělým selským zbojníkem. Zdálo by se např́ílad logické, že na krádeže dobytka se zaměří spíše loupežníci, kteří mají zkušenost s jeho chovem. Selský původ je $\mathrm{k}$ tomu jistě lepším předpokladem než původ z tuláckého, rasovského či řemeslnického prostředí. Neměli bychom se však nechat svést přímočarostí takové interpretace. Zdá se totiž, že větší zájem o krádeže dobytka mohl být dobově podmíněný. Současník událostí, František Vavák, vidí příčinu rozmachu podobných krádeží ve zrušení cechů, jež podle něj vedlo k nekalému obchodu s kradeným masem, které prodávali novopečení podnikatelé v řeznictví (Skopec 1915: 124). Zájem lupičů o dobytek tak evidentně souvisel se zájmem o maso na nelegálním trhu.

Kontaminace zbojnického a povstaleckého motivu je i v Karpatech ojedinělá, zjistili jsme ji jen u Ondráše a Juráše (Klvaňa 1904: 22). Zde se nabízí

Pan Douda, nar. 1929, Žandov (o. Kutná Hora), 23. května 2015. 
v zásadě dvojí linie pro vysvětlení: jednak prostřednictvím skutečnosti, že k tomuto spojení dochází v důsledku blízkosti fenoménu zbojnictví a rebelantství, jednak vysvětlení skrze konkrétní historické příčiny (v případě Kováříka shoda př́ijmení se selským vůdcem Ondřejem Vojtou).

\section{Závěr}

Na základě provedené analýzy můžeme říci, že vypravěčská tradice o loupežníku Kováŕíkovi, která se do dnešní doby dochovala jen ve zlomkovité podobě, by měla být svým původním rozsahem i významem srovnatelná s tradicí o nejvýznamnějších českých loupežnících.

Tradice o Kováříkovi se v některých aspektech odlišuje od ostatních loupežnických pověstí na území Čech, přičemž tyto vlastnosti jsou v pozoruhodné korelaci s prvky, které nacházíme v karpatské zbojnické tradici (krádeže dobytka, spojení loupežníka s rychtářem, povstalecký motiv).

Nabízí se hypotéza, že tato korelace souvisí s charakterem činnosti Jana Vojty a jeho bandy. Ta by podle dosud zjištěných skutečností mohla naplňovat ty definice zbojnictví, jejichž hlavním kritériem je zázemí zbojníků v selském prostředí. Tento předpoklad by mohl být inspirativním východiskem pro další historiografické bádání.

\section{Říjen 2017}

\section{Literatura a prameny}

Baláček, Bohuslav. 2006: Velimské pověsti. Velim: Nákladem autora.

Bartoš, Jaroslav. 1959. Komedie a hry českých lidových loutkářù. Praha: Orbis.

Drahovzal, Martin. 2007. Pověsti a kratochvilná vyprávění z Kouřimska a Kolínska. Kolín: Vlastní náklad.

Francek, Jindřich. 2002. Dějiny loupežnictva. Zloději, loupežníci, Iupiči, pytláci a žháři v českých dějinách. Praha: Rybka Publishers.

Gašparíková, Viera. 1964. Zbojník Michal Vdovec v histórii a folklóre gemerského l'udu. Bratislava: SAV.

Gašparíková, Viera. 1979. Povesti o zbojníkoch zo slovenských a polských Tatier. Bratislava: VEDA. Hobsbawm, Eric J. 1969. Bandits. London: Worcester.

Horváth, Pavel. 1988. Vznik a vývoj zbojníctva v slovenskej oblasti

Karpát. Slovenský národopis 36: 3-4: 407-428.

Hruschka, J. Nedat. (před 1933). Der Räuber Grasel in Böhmen und Mähren. České Budějovice. Jermář, Jaromír. 1996. Pověsti a vyprávění o Václavu Babinském na Mladoboleslavsku.

Středočeský vlastivědný sborník. Středočeské muzeum v Roztokách u Prahy, s. 15-29.

Klímová, Dagmar. 1983. K českým folklórním tradicím zbojnickým a loupežnickým. Slovenský národopis XXXI: 2: 185-196.

Klvaňa, Antonín. 1904. Pověsti o zbojnících Ondrášovi a Jurášovi. Český lid 13: 22. Kobzáň, Jan. 1984. U počátků vod. Ostrava: Profil.

Küther, Carsten. 1987. Räuber und Gauner in Deutschland. Das organisierte

Bandenwesen im 18. und frühen 19. Jahrhundert. 2. dopl. vyd. Götingen, Zürich. Luffer, Jan. 2014. Katalog českých démonologických pověstí. Praha: Academia. 
Mrštík, Jírí - Prchal, Josef. 1936: Kytička pověstí. Čáslav: Nákladem autora.

Novotný, Karel. 1922. Babinský. Praha.

Olbracht, Ivan. 1982. Loupežníci. In: Hory a staletí. Praha: Československý spisovatel: 77-112.

Oliva, Jan Valerian. 1939. Po stopách předků. Př́spěvek k 250leté památce usedlosti rodu Jana Olivy v Třeboníně na Čáslavsku (1687-1937). Praha.

Petzoldt, Laender. 1993. Sagen aus Steiermark. München: Diederichs.

Peuckert, Will-Erich. 1966. Schlesiche Sagen. Düsseldorf: Eugen Diederichs Verlag.

Pospíšil, Bohumil. 1995. Od Sázavy k Labi: pověsti kutnohorského regionu. Kutná Hora: Obzory Kutnohorska.

Procházka, Jaroslav. 1940. Z rodného kraje: příspěvek k rodové kronice. Kolín.

Ryšán Alois. 1954. Loupežnické povídky historické. Zbýšov. Strojopis uložen v SOkA Kutná Hora.

Salichová, Helena. 1951. Pověsti o Ondrášovi a Jurášovi. Radostná země 1: 167-169.

Schiebl, Jaroslav. 1933. Plzeň v pověsti, legendě, tradici a škádlivce. Sv. 1-2. Plzeň.

Schneider, Jaroslav. 1934. Staré pověsti a báje zlické z Kolínska, Kouřimska a okolních okresů. Kolín.

Schwär, Oskar. 1961. Volksgeschichten um Karasek und andere Oberlausitzer Räuber. Deutsches Jahrbuch für Volkskunde VII: 75-120.

Skopec, Jindřich (ed.). 1915. Paměti Františka J. Vaváka souseda a rychtáře Milčického z let 1770-1816. Kniha třetí, část I. Praha.

Skopec, Jindřich (ed.). 1918. Paměti Františka J. Vaváka souseda a rychtáře Milčického z let 1770-1816. Kniha třetí, část III. Praha.

Šalanda, Bohuslav. 1988. Ústní podání a dějiny. Praha: Univerzita Karlova.

Tůma, Josef. 1916. Staré pověsti zlické. Kolín: Nákladem autora.

Volf, Miloslav. 1934. Selské nepokoje na Červenopečecku za panství Bredova. Časopis pro dějiny venkova XXI: 3: 97-112, 157-174.

Votruba, Adam. 2010. Pravda u zbojníka. Zbojnictví a loupežnictví ve střední Evropě. Praha: Scriptorium.

Votruba, Adam. 2013. Jak jsem sbíral pověsti a jiné pověsti. Praha: Nákladem autora.

Ziegler, Václav. 2012. Pověsti z Peček a okolí. Praha: Galerie EfEf, s. r. o.

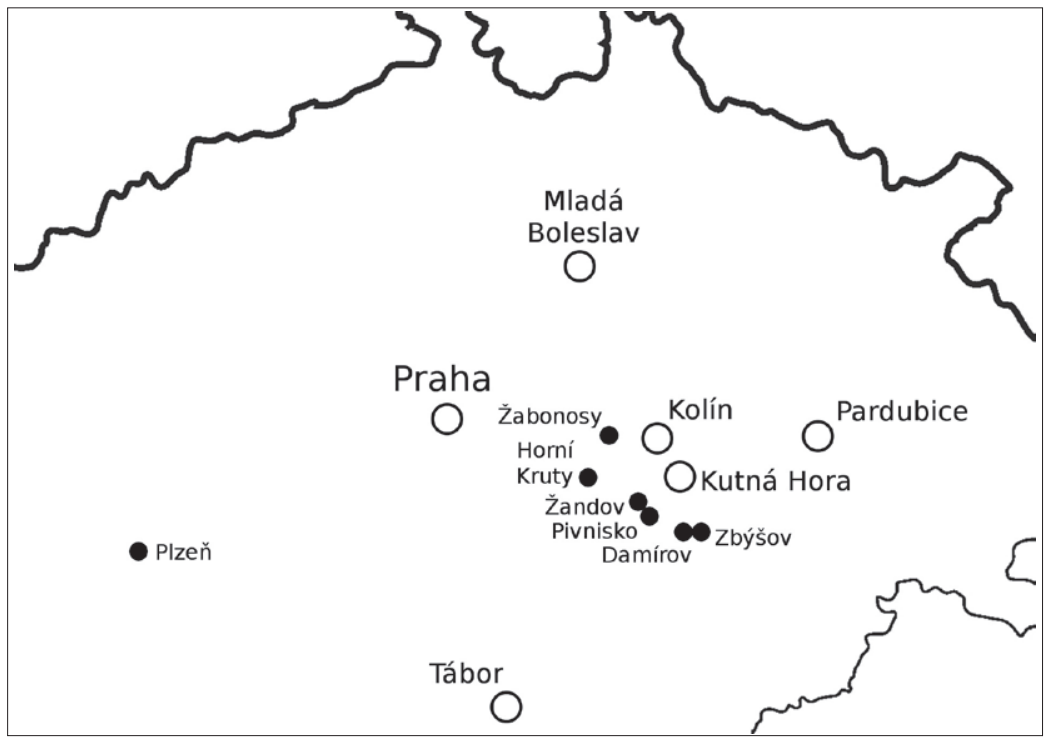

Místa, v nichž je prokázán výskyt pověstí o Kováříkovi (plná kolečka), mapa autor. 




Dobové vyobrazení Jana Vojty řečeného Kováříka. Královská kanonie premonstrátů na Strahově, Strahovská knihovna - grafická sbírka, inv. č. GS 6399.

\section{Soupis pověstí o Kovárííkovi}

Na prvním řádku zápisu je uváděno: pořadové číslo, název textu, rok zápisu, lokalita, odkaz. Na dalším řádku následuje stručný obsah pověsti nebo motivu pocházejícího z ústního tradování.

\section{A. Zapsané pověsti}

1. Loupežnická banda Kováříků v plzeňských lesích, 1933, Plzeň, Schiebl 1933, s. 36.

Kovářík posadil na cvočky starou výměnkářku, která o něm špatně mluvila. Byl chycen díky studentu Davidovi, který se nechal najmout loupežníky za kuchtíka; následně byl Kováŕík oběšen.

2. O Kovaříkovi a bohouňovickém rychtáři, 2011/2013, Horní Kruty (o. Kolín), vlastní sběr.

Kovařík byl ve spojení s rychtářem Vedralem v Bohouňovicích a schovával si u něj lup, Bohouňovičtí pak svého rychtáře vyhnali. 
3. Kovaříkova banda hraje karty, 2013, Žabonosy (o. Kolín), vlastní sběr.

Kovaříkova banda loupila tím způsobem, že někteří seděli s bohatými statkáři v hospodě a hráli karty, druzí mezitím loupili. Občas nechali někomu chudému za dveřmi kus masa $\mathrm{z}$ lupu.

4. Kováŕík v selském povstání, 2013, Žandov a Pivnisko (o. Kutná Hora), vlastní sběr.

Kováŕík se podílel na povstání proti baronovi, táhl s povstalci do Červených Peček.

B. Motivy z ústního podání v literárních textech

1. Jan Kovařík (hra pro loutkové divadlo), 1. pol. 19. stol., Rakovnicko (?), Bartoš 1959, s. 199.

Kovařík nechá posadit ženu, která o něm špatně mluvila, na prkno pobité hřeby.

2. Jan Kovařík (hra pro loutkové divadlo), 1. pol. 19. stol., Rakovnicko (?), Bartoš 1959, s. 190.

Kovařík obdaruje dceru chudého a zadluženého vesničana. Nechá si za to připravit na večer hostinu, což je uvedeno ve známost. Zatímco vojáci hlídají chalupu, loupežníci vyloupí slabě stř̌ežený zámek.

3. Loupežnické povídky historické, 1954, Zbýšov a okolí (o. Kutná Hora), Ryšán 1954, s. 5-8.

Kovářík daroval zbýšovskému mlynáři za pomoc podkovu. Ta pak přinášela tomu, kdo ji měl, štěstí.

4. Loupežnické povídky historické, 1954, Zbýšov a okolí (o. Kutná Hora), Ryšán 1954, s. 9-12.

Bratři Kováŕíci se pomstili správci za to, že je chtěl lapit. Předstírali, že ho chtějí pohřbít.

5. Loupežnické povídky historické, 1954, Zbýšov a okolí (o. Kutná Hora), Ryšán 1954, s. 14-18.

Podruh z Dobrovítova u sebe nechá nemocného Kováříka, ten mu po uzdravení věnuje tolar, který se v rodu dědí po ženské linii z matky na dceru.

6. Loupežnické povídky historické, 1954, Zbýšov a okolí (o. Kutná Hora), Ryšán 1954, s. 4.

Kováŕík vyloupil několikrát faru v Damírově, pročež byla přesunuta do Zbýšova a škola do Krchleb. 
7. Loupežnické povídky historické, 1954, Zbýšov a okolí (o. Kutná Hora), Ryšán 1954, s. 3.

Kováŕík popíjel v hospodě ve Zbýšově a několikrát platil za celou hospodu.

\section{Pověsti o Kováříkovi (nově nasbírané)}

V pověstech zachováváme podobu jména Kovářík, příp. Kovařík, podle vypravěče.

\section{O Kovaříkovi a bohouňovickém rychtáři}

Kovařík byl z Jindic u Janovic. On měl nějakou svoji partu a oni ho nemohli chytit. Představte si, že asi v sedmdesátejch letech opravovali v Žabonosech kostel a našli tam ve věži jeho pelech, kde on se ukrýval. Když žil, tak ho tam vždycky marně hledali, i když tam vedly do Žabonos stopy a teprve po letech to tam našli.

Pak ho hledali jednou v Bohouňovicích a našli tam lup u rychtáře Vedrala. Vedralové byli v Bohouňovicích rychtáři dlouholetý a on si tam u nich schovával lup. A Bohouňáci ho potom vystěhovali do Dolejších Krut, toho Vedrala, že ho nechtějí.

Ten Kovařík potom utek někam za Janovice, odkud pocházel, k těm Jindicům. Oni ho snad chytili v Jindicích, protože se tam stahovali i nějaký jeho spolupachatelé. Zavřeli ho na Špilberk a myslím, že jednou utek ze Špilberku. Tam se jinak nikomu nepodařilo utýct.

Vedralové pak žili v Dolních Krutech. Jeden z potomků tohohle rychtáře Vedrala pak měl hospodu, ale tak strašně okrádal ty sousedy, který tam chodili do hospody, že jim připisoval čárky a pak od nich chtěl pole a dostával pole. Tím vzrůstala jeho chalupa.

Jedna Vedralová se zase vdala do Újezdce za Šmejkala. Oni měli celkem velkej statek, ale ona mu ho tak zaneřádila, že se pak zpívalo:

U Chalupskejch v truhliku

mají švábi muziku,

Chalupskej vzal bič,

vypráskal je pryč.

Ono se totiž tomuhle Šmejkalovi ř́kalo Chalupák, nebo Chalupskej, protože tam těch Šmejkalů bylo víc, tak aby se to rozlišilo. Jinýmu Šmejkalovi se zas říkalo Baron.

Vyprávěla Miroslava Hlaváčková, nar. 1923, Horní Kruty

(okres Kolín), v listopadu 2011 a 15. ledna 2013. 


\section{Kovářík v selském povstání I.}

Kovárík se podílel na povstání. Táhli na zámek do Červenejch Peček. V Malešově udělal tu chybu, že jim dal na lačno napít. Pak táhli přes Bečváry. Nakonec měli hlad, byli spráskaný, vyšlo proti nim vojsko, takže dopadli jak sedláci u Chlumce. Kováŕík byl ze Žandova. V Pivnisku pobýval v čísle 23. Byl také v lištínském mlýně, tam byl ve spojení s mlynářem.

Vyprávěl Jaroslav Petránek, nar. 1929, Pivnisko

(okres Kutná Hora), 23. května 2013.

\section{Kovářík v selském povstání II.}

Kovářík se účastnil povstání proti baronovi. Táhli na zámek do Červenejch Peček.

Vyprávěl pán asi 70 let, Žandov (okres Kutná Hora), 23. května 2013.

\section{Kovaříkova banda hraje karty}

O Kovaříkovi se hodně vyprávělo. On se tady schovával na půdě kostela v Žabonosech.

Měli takový dvě party. Oni loupili tak, že ti lepší šli hrát někde do hospody karty. Tam seděli v hospodě s těma bohatejma statkářema a hráli s nima karty. A ty druhý mezitím loupili u nich ve stavení. Ukradli jim třeba obilí, nebo odvedli dobytek - tele, to pak někde zařezali a stáhli.

Chudejm oni občas něco podstrčili za dveře. Třeba jim tam dali kus masa.

To se tady taky stalo. Byla tu jedna chudá rodina, co měli hodně dětí, asi sedm nebo osm. Jmenovali se Balšánkovi. Ten Balšánek hrál taky karty a hodně prohrál. Tak pak dostal něco od Kovaříka. Ráno to našel za dveřma. Nevím, jestli už kus masa, nebo i nějaký peníze. Balšánkovi bydleli, jak je čtvrtý barák od transformátoru po levý straně [č. p. 85 - pozn. sběratele A. V.]. To, když se jde odtud směrem k nádraží.

O Kovaříkovi jsem slyšela vyprávět v mládí od starších žen. Vyprávělo se o něm při draní peří. Já jsem byla skoro ještě dítě, takže si z toho tolik nepamatuju.

Vyprávěla paní Hrachovinová, nar. 1927, Žabonosy

(okres Kolín), 3. května 2013. 